\title{
Effect of chromium yeast supplementation on performance, reproduction and immune function in pigs
}

\author{
Giovanni Savoinia*, Federica Cheli ${ }^{\mathrm{a}}$, Valentino Bontempo ${ }^{\mathrm{b}}$, \\ Antonella Baldi ${ }^{a}$, Francesco Fantuz ${ }^{\mathrm{a}}$, Iani Politis ${ }^{\mathrm{c}}$, Vittorio Dell'Orto ${ }^{\mathrm{a}}$ \\ a Istituto di Alimentazione Animale, Universita' di Milano, via Celoria 10, 20133 Milan, Italy \\ ${ }^{b}$ Dipartimento Scienze Animali Vegetali e dell'Ambiente, 86100 Campobasso, Italy \\ 'Delta Dairy SA, Athens, Greece
}

(Received 27 October 1997; accepted 22 April 1998)

\begin{abstract}
The aim of this study was to determine the effect of Cr-supplementation of lactating sow diet on sow performance, reproduction and immune functions. Sixteen hybrid commercial breed (Goland) sows were assigned to two experimental groups (eight sows/group; average parity $=2.3 \pm$ 0.4): control (no $\mathrm{Cr}$ supplementation) and $\mathrm{Cr}$-supplemented. Supplementation of $\mathrm{Cr}$ was carried out by adding Cr-yeast (Saccharomyces cerevisiae) from day 107 of gestation and during lactation. The following parameters were considered at day 3 , day 15 after parturition and at weaning: litter size, litter weight, sow body condition score and feed intake. At the same time blood samples were collected to measure superoxide production by blood neutrophils, interleukin-1 production (ILK-1) and major histocompatibility complex (MHC) class II expression by blood macrophages. Litter size, litter weight, sow body condition score and feed intake were not affected by $\mathrm{Cr}$-supplementation of sow diet. There were no significant differences in superoxide anion production by blood neutrophils, or ILK-1 production and MHC class-II antigen expression by blood macrophages when control and $\mathrm{Cr}$-supplemented sows were compared. (@ Elsevier / Inra)
\end{abstract}

chromium / immune response / pig

Résumé - Effet de la supplémentation de levure enrichie en chrome sur la croissance, la reproduction et sur la réponse immunitaire chez le porc. Le but de cette étude a été de déterminer l'effet de la supplémentation en chrome dans l'alimentation de la truie allaitante sur la croissance, la reproduction et la fonction immunitaire. Seize truies de race commerciale hybride (Goland) ont été sélectionnées pour former deux groupes expérimentaux (huit truies par groupe) : l'un supplémenté en chrome, l'autre non (contrôle). La supplémentation en chrome a été réalisée par addition dans l'alimentation de levure (Saccharomyces cerevisiae) enrichie en chrome, à partir de $107 \mathrm{j}$ de gesta-

* Correspondence and reprints

Tel.: (39) 2236912 16; fax: (39) 2706026 19; e-mail:savoini@imiucca.csi.unimi.it 
tion et durant toute la lactation. Les paramètres suivants ont été considérés à $3 \mathrm{j}$ et $15 \mathrm{j}$ après la mise bas et durant le sevrage : nombre d'animaux par portée, poids de la portée, condition physique des truies et prise alimentaire. Aux mêmes temps, des échantillons de sang ont été prélevés. Les paramètres immunitaires considérés ont été : la production de superoxydes par les neutrophiles sanguins, la production d'interleukine-1 et l'expression du complexe majeur d'histocompatibilité (MHC) de classe II par les macrophages sanguins. Le nombre d'animaux par portée, le poids de la portée, la condition physique des truies et la prise alimentaire n'ont pas été affectés par la supplémentation en chrome. Les productions de superoxydes par les neutrophiles sanguins ou d'interleukine-1 et l'expression des antigènes MHC de classe II ne sont pas différentes chez les animaux « contrôle » par rapport aux animaux supplémentés en chrome. (@ Elsevier/Inra)

\section{chrome / réponse immunitaire / porc}

\section{INTRODUCTION}

Chromium (Cr) influences several aspects of metabolism. The predominant biological role of $\mathrm{Cr}$ appears to be as a component of the glucose tolerance factor (GTF) to potentiate the action of insulin [2]. Moreover $\mathrm{Cr}$ influences protein synthesis, nucleic acid and lipid metabolism [2, 7]. Some authors failed to observe an increase of blood growth hormone when $\mathrm{Cr}$ was administered to pigs $[4,10]$. Reproductive efficiency is a primary factor determining the profitability of swine production. Accurate nutrition of the sow during gestation and lactation is an integral part of optimizing reproductive efficiency. It was considered probable that $\mathrm{Cr}$ could improve sow performance and condition in case of feeding an imbalanced diet. The administration of organic $\mathrm{Cr}$ to sows during pregnancy and lactation has been recognized to improve the litter size [6].

Moreover, parturition is a stressful event and a properly functioning immune response could have positive effects on both sows and piglets. A depression in the function of neutrophils and macrophages has been observed in dairy cows during early lactation [13]. However, such an immunosuppression has not been documented in the lactating sow. The manipulation of the natural defense mechanisms could be a useful mean of controlling the susceptibility to infections. The influence of $\mathrm{Cr}$ on the immune response has been investigated in swine and ruminants. Van Heugten and Spears [15] reported that $\mathrm{Cr}$ supplementation was not beneficial during immune stress in piglets. An improved cell-mediated and humoral immune response was observed in dairy cows fed supplemental $\mathrm{Cr}$ [3]. Positive effects of supplemental $\mathrm{Cr}$ on performance and immune status of stressed feeder calves have been reported $[8,16]$. Several sources of chromium such as chromium yeast, chromium picolinate, chromium nicotinate, exist. Chromium yeast is reported to be more bioavailable than chromic salts [5].

The objective of the present study was to examine the effects of supplementation of lactating sows diet with $\mathrm{Cr}$ yeast on sow performance, reproduction and immune function.

\section{MATERIALS AND METHODS}

Sixteen hybrid commercial breed (Goland) sows were used for the trial. The animals were chosen on the basis of parity (average $2.3 \pm 0.4$ ) and divided in two groups: control (no $\mathrm{Cr}$ supplementation) and $\mathrm{Cr}$-supplemented. The sows of the control group received a basal diet calculated to meet or exceed all nutrient requirements of lactating sows [9]. The composition of the basal diet is reported in table $I$. The sows of the supplemented group received the same diet plus $0.15 \mathrm{~g} / \mathrm{kg}$ as fed of Cr-yeast (Saccharomyces cerevisiae) (Crippsar Italiana, Italy) corresponding to $330 \mathrm{ppb}$ of $\mathrm{Cr}$. Diets were in meal form, stored at room temperature. Gravid sows were brought into clean farrowing facilities at day 107 of gestation and remained for a period that averaged 25 to 27 days for each farrowing group. 
Animals were fed the control or the Cr-supplemented diet at the rate of $1.8 \mathrm{~kg} /$ day from day 107 of gestation until parturition. During lactation, a step-up feeding program was used in which no feed was allowed on the day of parturition, and the amount was increased up to a maximum of $3 \mathrm{~kg}$ in each of two daily feedings by day 7 after farrowing and continued through-

Table I. Ingredient composition of sow diet $(\mathrm{g} / \mathrm{kg}$ of diet as fed).

\section{Ingredients}

\begin{tabular}{lr}
\hline Ground corn & 398.0 \\
Wheat middlings & 240.0 \\
Ground barley & 80.0 \\
Soybean meal (44\% CP) & 66.0 \\
Full fat soybean (flakes) & 59.0 \\
Herring meal & 30.0 \\
Dried beet pulp & 28.0 \\
Soybean oil & 20.0 \\
Fat & 13.6 \\
Meat meal (50\% CP) & 13.6 \\
Sunflower meal & 12.0 \\
Ground limestone & 11.6 \\
Molasses & 10.0 \\
Dicalcium phosphate & 6.4 \\
Vitamin and trace mineral premix & 4.0 \\
Salt & 3.2 \\
Sodium bicarbonate & 2.0 \\
L-lysine & 1.2 \\
Magnesium phosphate & 0.8 \\
Antibiotics & 0.6 \\
\hline
\end{tabular}

\section{Composition (\% as fed)}

$\begin{array}{ll}\text { Dry matter } & 87.6 \\ \text { Crude protein } & 16.3 \\ \text { Crude fat } & 7.5 \\ \text { Crude fiber } & 5.4 \\ \text { Ash } & 6.5 \\ \text { Calcium } & 0.96 \\ \text { Phosphorus } & 0.74 \\ \text { Lysine } & 0.9 \\ \text { Methionine + cystine } & 0.54\end{array}$

1 Expressed as kg of diet: 18000 IU of vitamin A; $2000 \mathrm{IU}$ of vitamin D; $30 \mathrm{mg}$ of vitamin $\mathrm{E} ; 4 \mathrm{mg}$ of vitamin $K, 2 \mathrm{mg}$ of vitamin $B 1,6 \mathrm{mg}$ of vitamin $B 2$, $3 \mathrm{mg}$ of vitamin B6, $0.02 \mathrm{mg}$ of vitamin B12,30 $\mathrm{mg}$ of vitamin PP, $0.1 \mathrm{mg}$ of biotine, $16 \mathrm{mg}$ of pantotenic acid, $0.6 \mathrm{mg}$ of folic acid, $600 \mathrm{mg}$ of coline, $4 \mathrm{mg}$ of BHT, $200 \mathrm{mg}$ of $\mathrm{FeCO}_{3}, 50 \mathrm{mg}$ of $\mathrm{CuO}, 2 \mathrm{mg}$ of $\mathrm{KI}$, $200 \mathrm{mg}$ of $\mathrm{ZnSO}_{4} \cdot \mathrm{H}_{2} \mathrm{O}, 80 \mathrm{mg}$ of $\mathrm{MnO}, 1.6 \mathrm{mg}$ of $\mathrm{CoCO}_{3} \cdot \mathrm{H}_{2} \mathrm{O}, 0.12 \mathrm{mg}$ of $\mathrm{Na}_{2} \mathrm{SeO}_{3}$. out the whole lactation. Within $36-48 \mathrm{~h}$ of birth piglets were given $100 \mathrm{mg}$ of iron dextran i.m. and offered creep feed ad libitum after 7 days.

Measurements were: total number of piglets born, alive at birth, at day 15 , and at weaning, litter weight at day 3, day 15 after parturition and at weaning. Sow body condition score, evaluated according to methods reported by [11], feed intake during lactation and the weaning-toestrus interval were recorded.

Blood samples were collected at 3 and 15 days after parturition and at piglets weaning from four sows in both groups (control and Cr-supplemented). Samples were collected for isolation of blood macrophages and neutrophils.

Blood leukocytes were isolated as described by Politis et al. [13]. Briefly, $15 \mathrm{~mL}$ of heparinized venous blood were mixed with $15 \mathrm{~mL}$ of Hanks' balanced salt solution (HBSS) (H2387, Sigma, St. Louis, USA) and layered onto $20 \mathrm{~mL}$ of Histopaque (H8889, Sigma), then centrifuged at $2500 \mathrm{rpm}$ for $45 \mathrm{~min}$ at $+8{ }^{\circ} \mathrm{C}$. Cells at the interface were collected for isolation of blood macrophages, whereas cells from the bottom layer were collected for isolation of blood neutrophils. Macrophages and neutrophils were assessed for viability by trypan blue exclusion (typically $>95 \%$ viable). Cells were then pelleted by centrifugation $\left(1500 \mathrm{rpm} \times 10 \mathrm{~min}\right.$ at $8^{\circ} \mathrm{C}$ ) and washed twice in HBSS. Cells were washed in RPMI 1640 medium (R5382, Sigma) and resuspended, at appropriate cell concentrations, in RPMI 1640 medium plus $10 \%$ fetal bovine serum (FBS) (F4135, Sigma) (macrophages) or in HBSS (neutrophils).

Superoxide anion production ( $\mathrm{nmol} / 10^{6}$ cells) by blood neutrophils, as a direct indicator of respiratory burst activation, was measured by the method described by Absolom [1]. The method described by Politis et al. [13] was used to evaluate interleukin- 1 production by blood macrophages. ILK-1 was quantified by its ability to increase proliferative response of thymic lymphocytes. An ELISA for measuring MHC classII determinants was performed as described by [12]. Results are expressed as change in absorbance per hour per $10^{6}$ cells.

Data were analyzed using a least squares ANOVA program [14]. The model included the effect of Cr-supplementation of sow diet (fixed). Data on immunological parameters were analyzed using a model including the effect of $\mathrm{Cr}$ supplementation of sow diet (fixed effect) and sampling time (fixed effect). 


\section{RESULTS AND DISCUSSION}

The results on the effect of $\mathrm{Cr}$-supplementation to lactating sow diet on a number of parameters indicative of sow performance and reproduction were examined (tables II, III).

The addition of Cr-yeast did not significantly influence litter size and litter weight (table II). Other works showed that Cr-supplementation, e.g., Cr-picolinate, of sow diet during the whole reproductive period, gestation and lactation improved litter size [6]. Differences between the two studies cannot be totally explained. One reasonable explanation is that in the present study $\mathrm{Cr}$ was fed starting only 1 week before parturition and during lactation. This was done because our goal was to evaluate whether the positive effect of $\mathrm{Cr}$ supplementation could be obtained supplementing sows only in the proximity of parturition.
Litter weights were not affected by the addition of $\mathrm{Cr}$ (table II) and this is in agreement with results obtained by others [6].

Sow body condition score (BCS) and daily feed intake were not affected by $\mathrm{Cr}$ supplementation (table III) even if Cr-supplemented sows suckled a litter of almost one piglet more. Therefore it can be supposed that $\mathrm{Cr}$ influenced positively utilization of several nutrients, most probably by potentiating the action of insulin as reported by Anderson [2] and Mertz [7]. Sows that consumed the Cr-supplemented diet showed a shorter, albeit not significant, weaning-to-estrus interval (table III). No improvement of $\mathrm{Cr}$-supplementation on days from weaning to estrus was found by other authors [6].

Considering measurements on immune function, $\mathrm{Cr}$-supplementation had no significant effect on any of the parameters tested. However, there were different tenden-

Table II. Least squares means of Cr-supplementation effects of sow diet on piglet performance.

\begin{tabular}{lcccc}
\hline $\begin{array}{l}\text { Response } \\
(n)\end{array}$ & $\begin{array}{c}\text { Control } \\
(8)\end{array}$ & $\begin{array}{c}\text { Cr-supplemented } \\
(8)\end{array}$ & S.E.M. & Significance \\
\hline $\begin{array}{l}\text { Litter size } \\
\text { Total born }\end{array}$ & 12.13 & 14.25 & 4.45 & NS \\
$\quad$ Born alive & 10.63 & 11.63 & 3.27 & NS \\
Day 15 & 9.12 & 9.88 & 1.21 & NS \\
Weaning & 9.00 & 9.88 & 1.17 & 0.07 \\
& & & & \\
Litter weight $(\mathrm{kg})$ & 20.53 & 20.74 & 5.61 & $\mathrm{NS}$ \\
$\quad$ Day 3 & 55.58 & 57.66 & 12.75 & $\mathrm{NS}$ \\
Day 15 & 79.70 & 82.83 & 18.12 & $\mathrm{NS}$ \\
Weaning & & & & \\
\hline
\end{tabular}

Table III. Least squares means of Cr-supplementation effects of sow diet on sow body condition score (BCS), feed intake during lactation and days from weaning to estrus.

\begin{tabular}{lcccc}
\hline Response & Control & Cr-supplemented & S.E.M. & Significance \\
\hline BCS at parturition & 3.0 & 3.0 & 0.32 & NS \\
$\quad$ at day 15 & 2.8 & 2.8 & 0.38 & NS \\
at weaning & 2.6 & 2.6 & 0.32 & NS \\
Daily feed intake (kg) & 4.8 & 4.9 & 0.43 & NS \\
Days to estrus post-weaning & 7.6 & 5.0 & 0.51 & NS \\
\hline
\end{tabular}



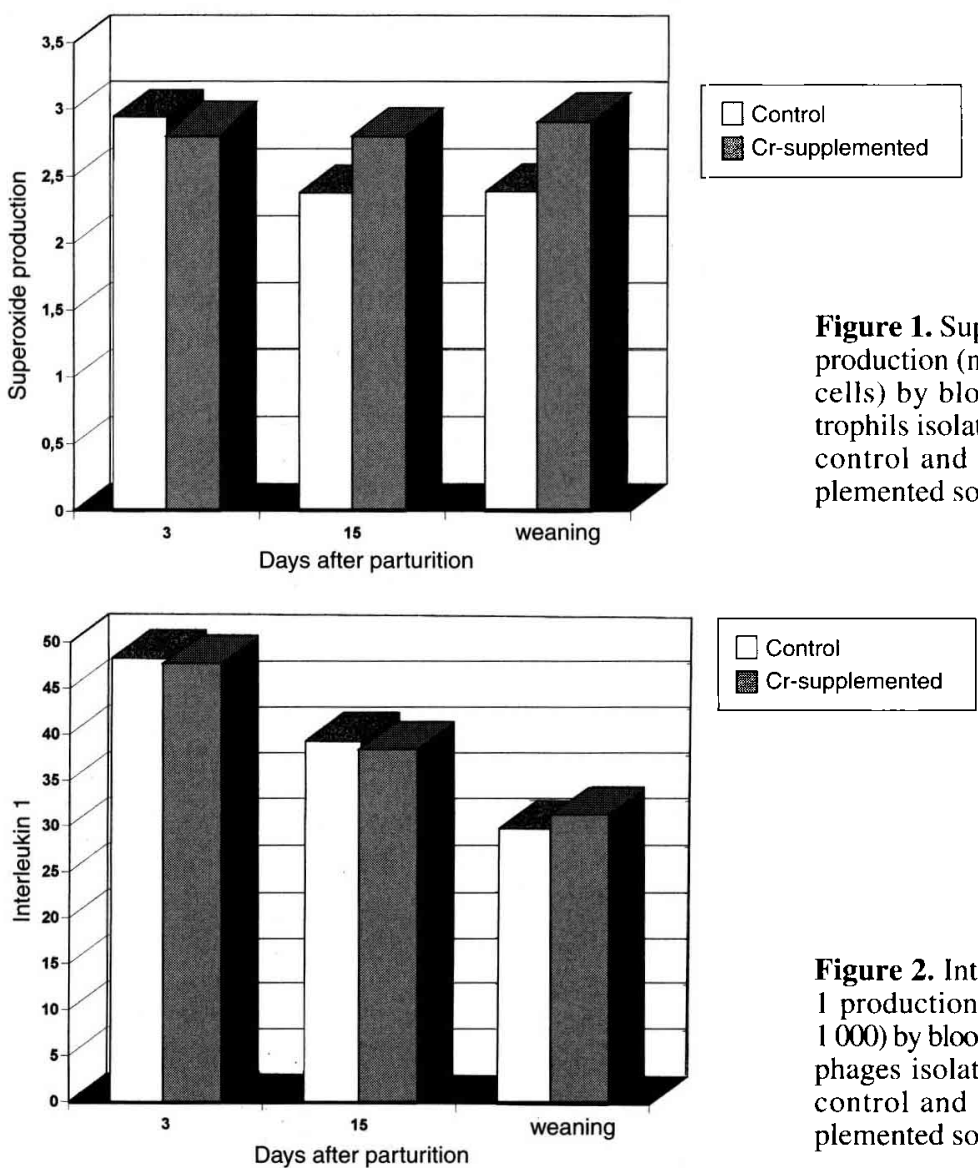

Figure 1. Superoxide production $\left(\mathrm{nmol} / 10^{6}\right.$ cells) by blood neutrophils isolated from control and $\mathrm{Cr}$-supplemented sows.

Figure 2. Interleukin 1 production $(\mathrm{cpm} \times$ 1000 ) by blood macrophages isolated from control and Cr-supplemented sows.

cies for the considered parameters. Superoxide production was similar on all sampling times (figure 1). ILK-1 did appear to decrease throughout the postpartum period (figure 2) while MHC class II production decreased and then increased (figure 3 ). These results are the first in sows and are in agreement with those reported by Van Heugten and Spears [15], who did not find any effect of $\mathrm{Cr}$ supplementation on immune response in piglets, opposed to data observed on cows [3]. The role of blood neutrophils and macrophages in the immune response is well recognized. Production of toxic radicals represents one of the most important defensive mechanisms of neutrophils. Concerning macrophages, the expression of major histocompatibilty complex molecules on the surface of macrophages and de novo synthesis of interleukin- 1 by activated macrophages are critical functions of the macrophages and are strict requirements for lymphocyte activation. The influence of $\mathrm{Cr}$ on the immune response is not well known. Chromium effect on immune response may be indirectly mediated by reduced cortisol blood levels. Cortisol is known to suppress functions of immunocompetent cells [16].

In conclusion, our results established that Cr-supplementation of sow diet 1 week before parturition and during lactation neither affect sow performance nor immunological parameters 

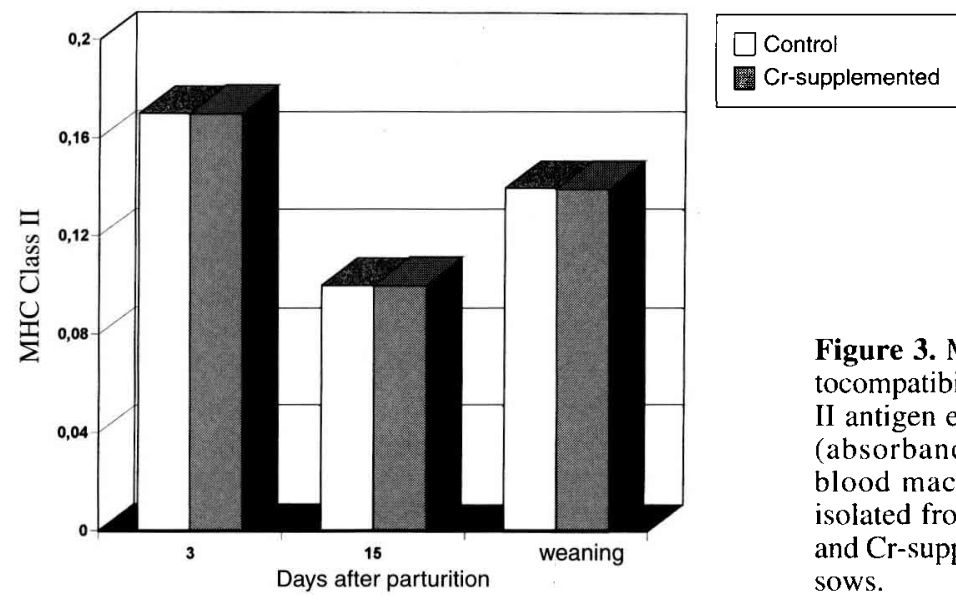

Figure 3. Major histocompatibility classII antigen expression (absorbance/h) by blood macrophages isolated from control and $\mathrm{Cr}$-supplemented sows.

\section{ACKNOWLEDGMENTS}

Supported by a grant from the Italian Ministry of Agriculture (MiRAAF)-RAIZ research project (paper no RZ181). The authors thank COMAZOO, CRIPPSAR and Mr. Bertocchi for technical assistance.

\section{REFERENCES}

[1] Absolom D.R., Basic methods for the study of phagocytosis, Methods Enzymol. 132 (1986) 95-180.

[2] Anderson R.A., Chromium, in: Mertz W. (Ed.), Trace elements in human and animal nutrition, Academic Press, San Diego, CA, 1987, pp. 109-115.

[3] Burton J.L., Mallard B.A., Mowat D.N., Effects of supplemental chromium on immune response of periparturient and early lactation dairy cows, J. Anim. Sci. 71 (1993) 1532-1539.

[4] Evock-Clover C., Polansky M.M., Anderson R.A., Steele N.C., Dietary chromium supplementation with or without somatotropin treatment alters serum hormones and metabolites in growing pigs without affecting growth performance, J. Nutr. 123 (1993) 1504-1512.

[5] Ewing W.N., Cole D.J.A., in: Context (Ed.), The living gut 117, Carrycastle Road, Dungannon, Co Tyrone, N., BT70 1LT Ireland, 1994.

[6] Lindemann M.D., Wood C.M., Harper A.F., Kornegay E.T., Anderson R.A., Dietary chromium picolinate additions improve gain:feed and carcass characteristics in growing-finishing pigs and increase litter size in reproduction sows, J. Anim. Sci. 73 (1995) 457-465.
[7] Mertz W., Chromium in human nutrition: a review, J. Nutr. 123 (1993) 626-633.

[8] Moonsie-Shageer S., Mowat D.N., Effect of level of supplemental chromium on performance, serum constituents, and immune status of stressed feeder calves, J. Anim. Sci. 71 (1993) 232-238.

[9] NRC, Nutrient Requirements of swine, Nat. Acad. Press, Washington, DC, USA, 1988.

[10] Page T.G., Southern L.L., Ward T.L., Thompson D.L. Jr., Effect of chromium picolinate on growth and serum and carcass traits of growing finishing pigs, J. Anim. Sci. 71 (1993) 656-662.

[11] Patience J.F., Thacker P.A., Swine nutrition guide, Prairie Swine Centre, University of Saskatchewan, USA, 1989.

[12] Politis I., Zhao X., McBride B.W., Burton J.H., Function of bovine mammary macrophages as antigen presenting cells, Vet. Immunol. Immunopathol. 30 (1992) 399-410.

[13] Politis I., Hidiroglou M., Batra T.R., Gilmore J.A., Gorewit R.C., Scherf H., Effects of vitamin E on immune function of dairy cows, Am. J. Vet. Res. 56 (1995) 179-184.

[14] SAS, SAS User's Guide: Statistics (Release 6.03), SAS Inst. Inc., Cary, NC, USA, 1988.

[15] Van Heugten E., Spears J.W., Immune response and growth of stressed weanling pigs fed diets supplemented with organic or inorganic forms of chromium, J. Anim. Sci. 75 (1997) 409-416.

[16] Wright A.J., Mowat D.N., Mallard B.A., Supplemental chromium and bovine respiratory disease vaccine for stressed calves, Can. J. Anim. Sci. 74 (1994) 287-295. 